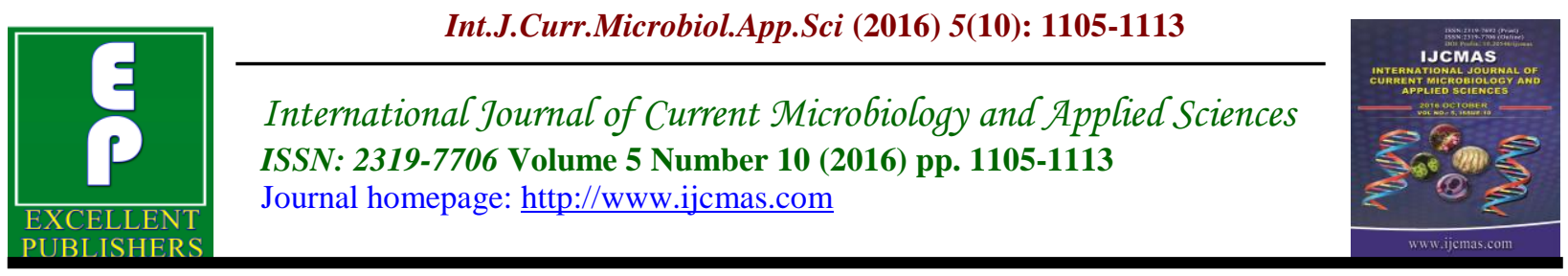

Original Research Article

http://dx.doi.org/10.20546/ijcmas.2016.510.116

\title{
Isolation of L-Asparaginase Producing Microbial Strains from Soil Samples of Telangana and Andhra Pradesh States, India
}

\author{
A.S. Lalitha Devi* and R. Ramanjaneyulu \\ Department of Microbiology, Sri Krishnadevaraya University, \\ Anantapuram, Andhra Pradesh-515003, India \\ *Corresponding author
}

\begin{tabular}{|c|c|}
\hline & A B S T R A C T \\
\hline $\begin{array}{l}\text { Ke y w or d s } \\
\text { L-asparaginase, } \\
\text { Soil samples, } \\
\text { biochemical } \\
\text { characterization, } \\
\text { microbial strains. }\end{array}$ & $\begin{array}{l}\text { L-Asparaginase fits to a cluster of homologous amidohydrolases which } \\
\text { catalyses the hydrolysis of aminoacid L-asparagine to L-aspartate and } \\
\text { ammonia. The present study deals with isolation of L-Asparaginase enzyme } \\
\text { producing bacterial strains, through serial diluting the soil samples from } \\
\text { different places of Telangana and Andhra Pradesh states, India. L- } \\
\text { asparaginase activity was detected on the basis of formation of pink colour } \\
\text { around the colony. A total of } 132 \text { colonies were screened and isolated from } \\
\text { all the samnles. }\end{array}$ \\
\hline $\begin{array}{l}\text { Accepted: } \\
\text { 28 September } 2016 \\
\text { Available Online: } \\
10 \text { October } 2016\end{array}$ & $\begin{array}{l}\text { L-asparaginase producers and poor L-asparaginase producers. This } \\
\text { experiment is mainly to isolate L-asparaginase producing microbial strains } \\
\text { collected from various soil samples. }\end{array}$ \\
\hline
\end{tabular}

\section{Introduction}

L-Asparaginase (EC 3.5.1.1) belongs to a group of homologous amidohydrolases family, which catalyses the hydrolysis of amino acid L-asparagine to L-aspartate and ammonia (Fernandes et al., 1997). They are naturally occurring enzymes expressed and produced by animal tissues, bacteria, plants, and in the serum of certain rodents, but not in mankind (Muthusivaramapandian et al., 2008). Large number of microorganisms that include Erwinia carotovora (Cammack et al., 1972), Pseudomonas stutzeri (Manna et al., 1995), Pseudomonas aerugenosa (Abdel-Fatteh et al., 2002) and E. coli (Qin et al., 2003) has been known to produce L- asparaginase. Different types of asparaginase can be used for different industrial and pharmaceutical purposes. Asparaginases are used to reduce the formation of acrylamide, a suspected carcinogen, in starchy food products such as snacks and biscuits (Bansal et al., 2010). By adding asparaginase before baking or frying the food, asparagine is converted into another common amino acid, aspartic acid, and ammonium.

L-Asparaginase has received increased attention in recent years for its anticarcinogenic potential and is used as a 
chemotherapeutic agent for acute lymphocytic leukemia and less frequently for acute myeloblastic leukemia, chronic lymphocytic leukemia, Hodgkin's disease, melonosarcoma and non-Hodgkin's lymphoma (Bansal et al., 2010; Duval et al., 2002; Pieters et al., 2011). The reason it is preferred for this purpose is that, it is biodegradable, non-toxic and can be administered at the local site quite easily. The aim of this research is to produce Lasparaginase from soil bacteria.

\section{Materials and Methods}

\section{Collection of samples}

The following samples were collected from the rhizosphere of different crop plants at various places of Telangana and Andhra Pradesh states with a view to isolate potent L-Asparaginase producing microorganisms.

The different soil sources are:

\section{Sample I}

This soil sample was collected from the Paddy field at Manoharabad Rangareddy district, Andhra Pradesh.

\section{Sample II}

This soil sample was collected from the Vegetable field at Anakapalli, Vizag district, Andhra Pradesh.

\section{Sample III}

The soil sample was collected from Ground nut field at Nandyal, Kurnool district, Andhra Pradesh.

\section{Sample IV}

The sample was collected from Sun flower field at Miriyala guda, Nalgonda district, Telangana.

\section{Sample V}

This soil sample was collected from the Red gram field at Eluru, East Godavari district Andhra Pradesh.

\section{Sample VI}

This soil sample collected from the Pearl Millet field at Sanga reddy, Medak district, Telangana.

\section{Sample VII}

This soil sample collected from the Seasame field at Armoor, Nizamabad district, Telangana.

\section{Sample VIII}

This soil sample collected from the sea coast of Vizag. Vishakhapatnam district, Andhra Pradesh.

\section{Sample IX}

This soil sample collected near Hussain Sagar Lake, Hyderabad district, Telangana.

All the samples were collected in sterile screw capped tubes and care was taken see that the source had different soil characteristics and was from diverse geographical locations.

\section{Screening and isolation of bacteria}

\section{Isolation of bacteria}

Different soil samples treated for bacterial isolation by serial dilution technique using nutrient agar medium 8. Antifungal agents (Fluconazole 75ug/ml, Ketocanazole$75 \mathrm{ug} / \mathrm{ml}$ ) were added to control the fungal contamination. The inoculated agar plates were incubated at $37^{\circ} \mathrm{C}$ for $24 \mathrm{hrs}$. 
Screening of L-Asparaginase producing micro organisms

About $1 \mathrm{gm}$ of each of the above samples was taken into separate conical flasks. The suspension was kept on rotary shaker for 30 min and kept aside to settle the suspending matter. $1 \mathrm{ml}$ of the supernatant was serially diluted with sterile water. $1 \mathrm{ml}$ each, of 10-5 dilutions were added to $20 \mathrm{ml}$ of sterile modified M9 medium (as described below) maintained at $45^{\circ} \mathrm{C}$, mixed thoroughly and plated in $10 \mathrm{~cm}$ diameter sterile petridishes and incubated at $37^{\circ} \mathrm{C}$. Antifungal agents

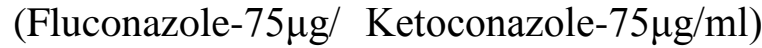
were incorporated to control the fungal contamination. After $24 \mathrm{~h}$ of incubation, the selected bacterial colonies with pink zones around them were picked up and transferred onto M-9 medium slants (Gulati et al., 1997). Control plates were of modified M9 medium without dye and without Lasparagine. The zone and colony diameter were measured after 24 hours. Colonies with pink zones around the colony were considered as L-asparaginase producing strains.

\section{The composition of M-9 medium is (g/l)}

$\mathrm{Na}_{2} \mathrm{HPO}_{4} .2 \mathrm{H}_{2} \mathrm{O}, 6 ; \mathrm{KH}_{2} \mathrm{PO}_{4}, 3 ; \mathrm{NaCl} 0.5 ; \mathrm{L}-$ asparagine, $5 ; 1 \mathrm{M} \mathrm{MgSO}{ }_{4} .7 \mathrm{H}_{2} 0,2 \mathrm{ml} ; 0.1 \mathrm{M}$ $\mathrm{CaCl}_{2} \quad 2 \mathrm{H}_{2} \mathrm{O}, \quad 1 \mathrm{ml} ; 20 \%$ Glucose stock solution $10 \mathrm{ml}$, Agar, 20 phenol red indicator (2.5\%): 0.04-0.36 ml, $\mathrm{pH} 7.0$.

\section{Secondary screening}

Submerged fermentation studies were also carried out in order to further screen out those producing less enzyme. Quantitative estimations of enzyme activities were carried out using M-9 medium. Erlenmeyer flasks $(250 \mathrm{ml})$ containing $50 \mathrm{ml}$ of the M-9 medium were inoculated with each of the test organisms. The flasks were incubated at $37^{\circ} \mathrm{C}$ at $250 \mathrm{rpm}$ for $48 \mathrm{~h}$, in a controlled environment shaker-incubator. Uninoculated medium served as control. The flask contents were centrifuged at $4000 \mathrm{rpm}$ for 15 min. The enzyme activities were estimated in culture filtrates by Nesslerization (Gulati et al., 1997) and expressed as $\mathrm{IU} / \mathrm{ml}$. One international unit of L-asparaginase activity is defined as that amount of enzyme which catalyses the formation of $1 \mu \mathrm{m}$ of ammonia per min under the conditions of the assay. Standard graph (Fig-2) was prepared by treating $1 \mathrm{ml}$ of $0.25,0.5,0.75$ and $1 \mathrm{mM}$ ammonium sulphate with trichloroacetic acid, $\mathrm{NaOH}$ and Nessler's reagent.

\section{Stock solution of $10 \mathrm{mM}$}

It was prepared by dissolving $132 \mathrm{mg}$ of ammonium sulphate in $100 \mathrm{ml}$ distilled water in a volumetric flask.

\section{Working solution of $1 \mathrm{mM}$}

It was prepared by taking $5 \mathrm{ml}$ of stock solution and made up to $50 \mathrm{ml}$ with distilled water. From this 0.25 and $0.5 \mathrm{mM}$ were prepared.

Procedure: Into a series of test tubes, $2 \mathrm{ml}$ of $(0.05 \mathrm{M})$ borate buffer was taken. To this $1 \mathrm{ml}$ of each $1 \mathrm{mM}, 0.75 \mathrm{mM}, 0.5 \mathrm{mM}$ and $0.25 \mathrm{mM}$ of working solutions were added. From this $1 \mathrm{ml}$ sample was withdrawn and delivered into $2.5 \mathrm{ml}$ of $0.1 \mathrm{~N}$ trichloroacetic acid. To this $1 \mathrm{ml}$ of $1 \mathrm{~N} \mathrm{NaOH}$ was added. $0.2 \mathrm{ml}$ of EDTA (0.1M) was added to each sample to overcome the encountered turbidity. After $2 \mathrm{~min}$., $0.5 \mathrm{ml}$ of Nessler reagent was added. The OD was measured after $5 \mathrm{~min}$. at $425 \mathrm{~nm}$.Blank was prepared by adding $1 \mathrm{ml}$ of water instead of ammonium sulphate solutions. The data is shown in Table -2. A standard curve was constructed by taking ammonium sulphate 
$(\mu \mathrm{M} / \mathrm{ml})$ on $\mathrm{X}$-axis and corresponding optical density on $\mathrm{Y}$-axis and the data is shown in Fig. 2. One unit (IU) is defined as the amount of enzyme that released $1 \mu$ mole of ammonia from L-asparagine per minute at $\mathrm{pH} 8.5$ at $37^{\circ} \mathrm{C}$.

\section{Assay \\ Procedure for production and assay of L- asparaginase}

The selective promising isolate LA-26 was subcultured onto M-9 solid medium and incubated at $37^{\circ} \mathrm{C}$ for $24 \mathrm{~h}$.. The growth contents of the slant was suspended in $5 \mathrm{ml}$ of sterile water and transferred into $250 \mathrm{ml}$ EM flask containing $50 \mathrm{ml} \mathrm{M-9} \mathrm{medium.}$

All the production flasks were incubated on rotary shaker for $24 \mathrm{~h}$. At the end of incubation period, $10 \mathrm{ml}$ of the cell suspension was taken and centrifuged. Quantitative detection was carried out by a Nesslerization method. A $0.5 \mathrm{ml}$ sample of cell suspension, $1.0 \mathrm{ml}$ of $0.1 \mathrm{M}$ sodium borate buffer $(\mathrm{pH} 8.5)$ and $0.5 \mathrm{ml}$ of $0.04 \mathrm{M}$ L-asparagine solution were mixed and incubated at $37^{\circ} \mathrm{C}$ for $10 \mathrm{~min}$. The reaction was then stopped by the addition of $0.5 \mathrm{ml}$ of $0.1 \mathrm{~N}$ trichloroacetic acid.

The precipitated protein was removed by centrifugation and the liberated ammonia was determined by direct nesslerization. Each sample was individually mixed with $1 \mathrm{ml}$ of $1 \mathrm{~N} \mathrm{NaOH}$ and $0.2 \mathrm{ml}$ of $0.1 \mathrm{M}$ EDTA was added. After 2 min. $0.5 \mathrm{ml}$ of nessler's reagent was added and mixed. Suitable blanks of substrate and enzyme containing sample were included in all assays. After 5 min. from the addition of Nessler's reagent to the sample, the optical density of the sample was read at $450 \mathrm{~nm}$. The results are presented in Table 3.4.

\section{Calculation}

Micromoles ammonia released
Units/ml=--- 10 minutes x ml enzyme in reaction

\section{Results and Discussion}

\section{Primary screening}

In the present investigation L-Asparaginase enzyme producing bacterial strains were isolated by serial diluting the soil samples and spreading the same on agar plates as performed by El-Bessoumy et al., 2004. Lasparaginase activity was detected on the basis of formation of pink colour around the colony. A total of 132 colonies were selected and isolated from all the samples based on pink colour zones around the colonies (Fig 1). The number of isolates from each sample is given in Table 1. Likewise efficient L- asparaginase producing bacteria were screened (Kamble et al., 2012). Out of 132 isolates, 36 were selected based on the zone of clearance and their macroscopic characters, eliminating those that appeared similar. It is proposed that strain exhibiting zone of diameter above $0.9 \mathrm{~cm}$ are referred as good L-asparaginase producers, those strains with zone diameter of $0.6-0.9 \mathrm{~cm}$ and those having below 0.6 $\mathrm{cm}$ zone diameter may be referred to as moderate and poor L-asparaginase producers respectively. The selected isolates were transferred onto nutrient agar slants and incubated for $24 \mathrm{~h}$.

\section{Secondary screening}

The cultures showing maximum activity in screening were used for the production of $\mathrm{L}$ Asparaginase enzyme by the help of shake flask fermentation as done by (Mohana Priya et al., 2011). 
Table.1 L-asparaginase producing isolates from various samples

\begin{tabular}{|c|c|c|c|c|}
\hline \multicolumn{2}{|c|}{ Sample no and source } & Number of isolates & Selected isolates & Zone of colouration $(\mathrm{cm})$ \\
\hline $\begin{array}{l}\text { Sample } \\
\text { I }\end{array}$ & Paddy & 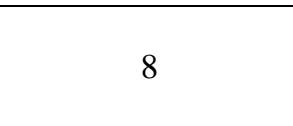 & $\begin{array}{l}\text { LA-1 } \\
\text { LA-2 } \\
\text { LA-3 }\end{array}$ & $\begin{array}{l}0.8 \\
0.8 \\
1.1\end{array}$ \\
\hline $\begin{array}{l}\text { Sample } \\
\text { II }\end{array}$ & Vegetable & 15 & $\begin{array}{l}\text { LA-4 } \\
\text { LA-5 } \\
\text { LA-6 } \\
\text { LA-7 } \\
\text { LA-8 }\end{array}$ & $\begin{array}{l}0.9 \\
0.8 \\
1.0 \\
1.1 \\
1.2 \\
\end{array}$ \\
\hline $\begin{array}{c}\text { Sample } \\
\text { III }\end{array}$ & Ground nut & 6 & $\begin{array}{l}\text { LA-9 } \\
\text { LA-10 }\end{array}$ & $\begin{array}{l}1.1 \\
0.9\end{array}$ \\
\hline $\begin{array}{c}\text { Sample } \\
\text { IV }\end{array}$ & Sun flower & 35 & $\begin{array}{l}\text { LA-11 } \\
\text { LA-12 } \\
\text { LA-13 } \\
\text { LA-14 } \\
\text { LA-15 } \\
\text { LA-16 } \\
\text { LA-17 } \\
\text { LA-18 } \\
\text { LA-19 }\end{array}$ & $\begin{array}{l}0.9 \\
1.0 \\
0.9 \\
0.8 \\
1.1 \\
1.1 \\
1.2 \\
1.1 \\
1.1\end{array}$ \\
\hline $\begin{array}{c}\text { Sample } \\
\text { V }\end{array}$ & Red gram & 33 & $\begin{array}{l}\text { LA-20 } \\
\text { LA-21 } \\
\text { LA-22 } \\
\text { LA-23 } \\
\text { LA-24 } \\
\text { LA-25 } \\
\text { LA-26 }\end{array}$ & $\begin{array}{l}0.9 \\
1.1 \\
1.2 \\
1.3 \\
1.1 \\
0.9 \\
1.3 \\
\end{array}$ \\
\hline $\begin{array}{c}\text { Sample } \\
\text { VI }\end{array}$ & Pearls millet & 2 & LA-27 & 1.0 \\
\hline $\begin{array}{c}\text { Sample } \\
\text { VII }\end{array}$ & Sesame & 11 & $\begin{array}{l}\text { LA-28 } \\
\text { LA-29 } \\
\text { LA-30 } \\
\end{array}$ & $\begin{array}{l}0.9 \\
1.0 \\
0.9 \\
\end{array}$ \\
\hline $\begin{array}{c}\text { Sample } \\
\text { VIII }\end{array}$ & Marine & 9 & $\begin{array}{l}\text { LA-31 } \\
\text { LA-32 } \\
\text { LA-33 }\end{array}$ & $\begin{array}{l}0.9 \\
0.9 \\
0.9\end{array}$ \\
\hline $\begin{array}{l}\text { Sample } \\
\text { IX }\end{array}$ & Lake & 13 & $\begin{array}{l}\text { LA-34 } \\
\text { LA-35 } \\
\text { LA-36 }\end{array}$ & $\begin{array}{l}1.0 \\
0.9 \\
1.2\end{array}$ \\
\hline
\end{tabular}

Table.2 Construction of standard graph for Ammonium Sulphate

\begin{tabular}{|c|c|}
\hline $\left.\mathbf{( N H}_{4}\right)_{2} \mathbf{S O}_{\mathbf{4}}$ conc. $(\boldsymbol{\mu M} / \mathbf{m l})$ & Optical Density $(\mathbf{n m})$ \\
\hline 0.1 & 0.076 \\
\hline 0.2 & 0.152 \\
\hline 0.3 & 0.228 \\
\hline 0.4 & 0.304 \\
\hline 0.5 & 0.381 \\
\hline 0.6 & 0.458 \\
\hline 0.7 & 0.515 \\
\hline 0.8 & 0.582 \\
\hline
\end{tabular}


Table.3 Activities of the selected isolates

\begin{tabular}{|c|c|}
\hline Isolates & L-asparaginase activity IU/ml \\
\hline LA-1 & 3.0 \\
\hline LA-2 & 2.0 \\
\hline LA-3 & 2.9 \\
\hline LA-4 & 3.8 \\
\hline LA-5 & 2.8 \\
\hline LA-6 & 2.7 \\
\hline LA-7 & 3.4 \\
\hline LA-8 & 3.7 \\
\hline LA-9 & 3.6 \\
\hline LA-10 & 3.2 \\
\hline LA-11 & 2.9 \\
\hline LA-12 & 3.3 \\
\hline LA-13 & 3.0 \\
\hline LA-14 & 3.8 \\
\hline LA-15 & 3.3 \\
\hline LA-16 & 2.8 \\
\hline LA-17 & 2.9 \\
\hline LA-18 & 2.7 \\
\hline LA-19 & 2.9 \\
\hline LA-20 & 2.9 \\
\hline LA-21 & 3.8 \\
\hline LA-22 & 3.9 \\
\hline LA-23 & 3.9 \\
\hline LA-24 & 3.5 \\
\hline LA-25 & 3.2 \\
\hline LA-26 & 4.1 \\
\hline LA-27 & 3.2 \\
\hline LA-28 & 3.2 \\
\hline LA-29 & 3.0 \\
\hline LA-30 & 2.8 \\
\hline LA-31 & 2.9 \\
\hline LA-32 & 2.8 \\
\hline LA-33 & 3.3 \\
\hline LA-34 & 3.3 \\
\hline LA-35 & 3.5 \\
\hline LA-36 & 3.6 \\
\hline
\end{tabular}


Fig.1 Rapid plate assay to screen for 1-asparaginase producing bacteria

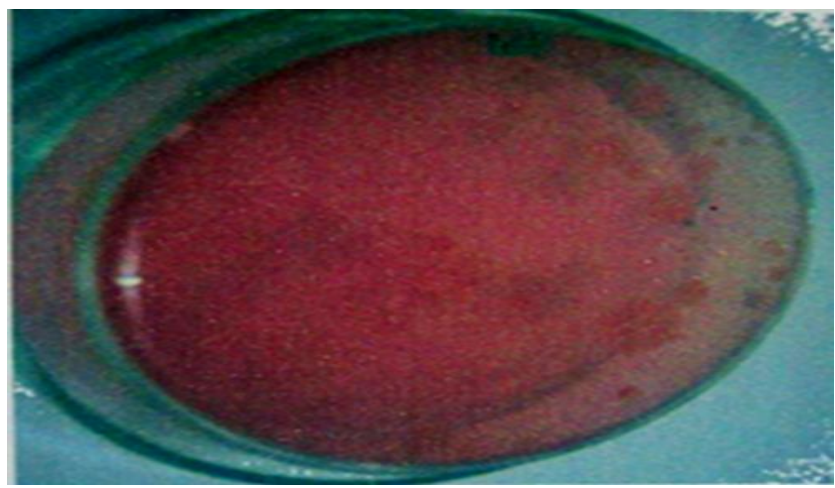

Fig.2 Standard Graph of Ammonium Sulphate

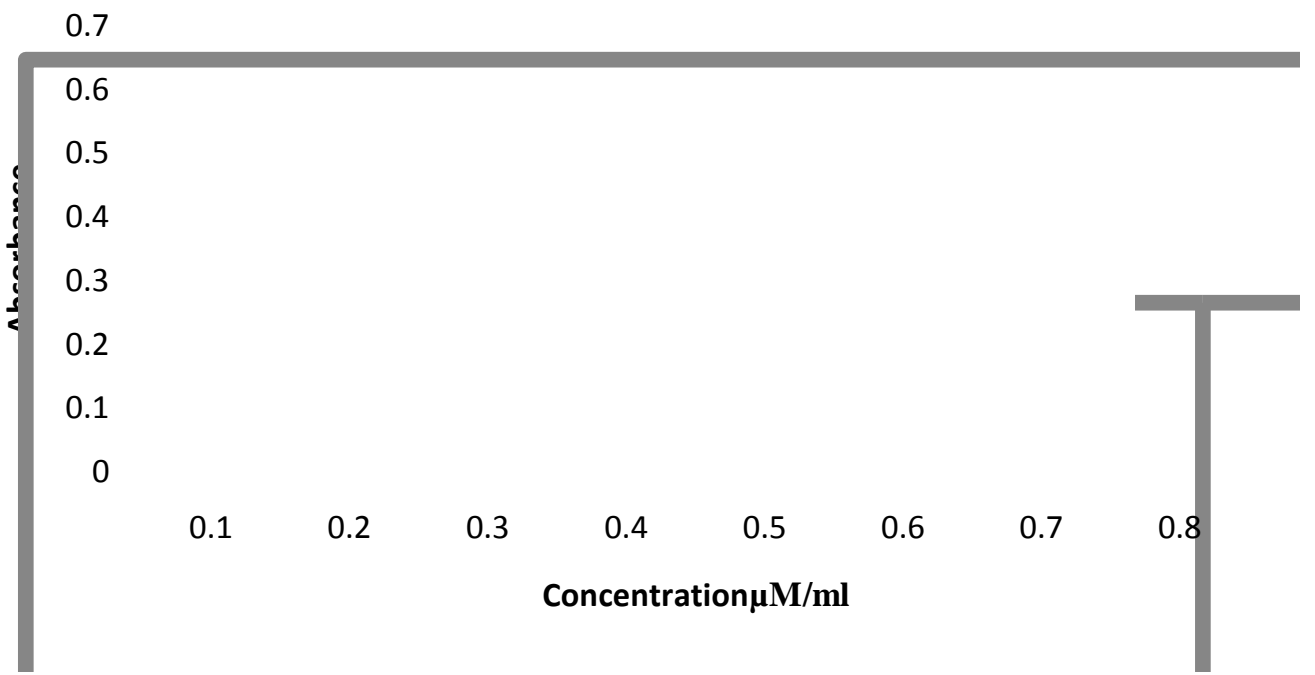

The selected isolates were further screened for L-asparaginase activity in M-9 medium under submerged fermentation conditions. Asparaginase activities were routinely determined by direct nesseleriztion as described by Mashburn and Wriston where the rate of hydrolysis of asparagine is obtained by measuring released ammonia.

One unit of activity is that amount of enzyme necessary to catalyze the formation of $1 \mu$ mole of ammonia per min under the conditions of the assay. The ammonia released is estimated from the ammonium sulphate standard graph (Table: 2.Fig-2).
The results of secondary screening are presented in Table-3. The results indicated that the isolate LA-26 exhibited maximum L-asparaginase activity $(4.0 \mathrm{U} / \mathrm{ml})$ followed by the isolates LA-22 $(3.9 \mathrm{U} / \mathrm{ml})$. Hence further studies were focused on the isolate LA-26. To perform further investigation, the selected LA-26 strain was grown on M9 medium and incubated at $37^{\circ} \mathrm{C}$ for $18 \mathrm{~h}$ and stored until use at $4^{\circ} \mathrm{C}$ in refrigeration. The isolate LA-26 showing maximum Lasparaginase production was identified by the help of morphological and biochemical tests as per Bergery's manual. 
A total of 132 colonies were selected which are asparaginase producing bacteria were isolated from eight different soil samples. This may be attributed to the fact that soil is a rich source for potential enzyme producing organisms. In this study, the result of screening test revealed that asparaginase producing bacteria were able to hydrolyse Lasparagine since they utilized L-asparagine as their substrate and breakdown asparagine to L-aspartate and ammonia which further reacts with water to produce $\mathrm{NH} 4 \mathrm{OH}$, hence the $\mathrm{pH}$ of the medium is basic which subsequently changes the medium from yellow to red, hence the red zone observed around the colony of asparaginase producing bacteria.

This is in accordance with the work of Gulati et al., (1997) who proved that colour transformation was due to L-asparaginase production. Strain exhibiting zone of diameter above $0.9 \mathrm{~cm}$ are referred as good L-asparaginase producers, those strains with zone diameter of $0.6-0.9 \mathrm{~cm}$ and those having below $0.6 \mathrm{~cm}$ zone diameter may be referred to as moderate and poor Lasparaginase producers respectively.

In conclusion, this study clearly indicates that soil can provide a good source of asparaginase producing bacteria and the strains subjected to submerged fermentation at an alkaline $\mathrm{pH}(\mathrm{pH}$ 6-8) using will produce reasonable amount of Lasparaginase.

\section{Acknowledgements}

We are highly acknowledged to the Head, Department of Microbiology, Sri Krishnadevaraya University, Anatapuram, Andhra Pradesh, INDIA-515003 for providing facilities in department to pursue this research work.

\section{References}

Abdel-Fatteh, Y., Olama, Z.A. 2002. Lasparaginase produced by Pseudomonas aeruginosa in solid state culture: evaluation and optimization of culture conditions using factorial designs. Process Biochem., 38: 115122.http://dx.doi.org/10.1016/S00329592(02)00067-5

Bansal, S., Gnaneswari, P., Mishra, P., Kundu, B. 2010. Structural stability and functional analysis of Lasparaginase from Pyrococcus furiosus. Biochem., 75(3): 375-381.

Cammack, K.A., Marlborough, D.I., Miller, D.S. 1972. Physical properties and subunit structure of L-asparaginase isolated from Erwinia carotovora. J. Biochem., 126: 361-379.

Duval, M., Suciu, S., Ferster, A., Rialland, X., Nelken, B., Lutz, P., Benoit, Y., et al. 2002. Comparison of Escherichia coli Asparaginase with Erwinia asparaginase in the treatment of childhood Lymphoid malignancies. Results of a randomized European organization for research and treatment of cancer-children's leukemia group phase 3 trails. Blood, 99: 2734-2739. http://dx.doi.org/10.1182/blood.V99.8. 2734

El-Bessoumy, A.A., Sarhan, M., Mansour, J. 2004. Production, isolation, and purification of L-asparaginase from Pseudomonas Aeruginosa 50071 using solid-state fermentation. J. Biochem. Mol. Biol., 37: 387- 393.

Fernandes, A.I., Gregoriadis, G. 1997. Polysialylated asparaginase: preparation, activity and pharmacokinetics. Biochem. Biophys. Acta., $\quad$ 1341: 26-34. http://dx.doi.org/10.1016/S01674838(97)00056-3 
Gulati, R., Saxena, R.K., Gupta, R.A. 1997. Rapid Plate Assay for Screening LAsparaginase Producing Microorganisms. Lett. Appl. Microbiol., 24: 23-26. http://dx.doi.org/10.1046/j.1472765X.1997.00331.x.

Hosamani, R., Kaliwal, B.B. 2011. Lasparaginase an anti-tumor agent production by Fusarium equiseti using solid state fermentation. Inter. J. Drug Discovery, 3(2): 88-99.

Imada, A., Igarasi, S., Nakahama, K., Isono, M.. 1973. Asparaginase and glutaminase activities of microorganisms. J. Gen. Microbiol., 76: 85-89. http://dx.doi.org/10.1099/0022128776-1-85.

Kamble, K.D., Khade, P.J. 2012. Studies on antineoplastic enzyme producing bacteria from soil. Inter. $J$. Pharmaceut. Biomed. Res., 2: 94-99.

Manna, S., Sinaha, A., Sadhukhan, R., Chakrabarty, S.L. 1995. Purification, characterization and antitumor activity of Lasparaginase isolated from Pseudomonas stutzeri. MB-405. Curr. Microbiol., 730: 291-298. http://dx.doi.org/10.1007/BF00295504 Mohana Priya, P., Radhakrishnan, M., Balagurunathan, R. 2011. Production and optimization of L-asparaginase from Streptomyces sp (TA22) isolated from Western Ghats, India, J. Chem. Pharm. Res., 3(4): 618-624.

Muthusivaramapandian, $\quad$ M., Arrivukkarasan, S., Aravindan, R., Viruthagiri, T. 2008. Perspectives and Applications of anticancer enzyme Lasparaginase. Asian J. Microbiol. Biotechnol. Environ. Sci., 10(4): 851854.

Pieters, R., Hunger, S.P., Boos, J., Rizzari, C., Silverman, L., Baruchel, A., Goekbuget, N., Schrappe, M., ChingHon Pui. 2011. Cancer, 117(2): 238249.

http://dx.doi.org/10.1002/cncr.25489

Qin, M., Zhao, F. 2003. L-asparaginase release from Escherichia coli cells with aqueous two-phase micellar systems. Appl. Biochem. Biotechnol., 110(1):

$11-21$ http://dx.doi.org/10.1385/ABAB:110: $1: 11$

Verma, N., Kumar, K., Kaur, G., Anand, S. 2007. Escherichia coli K-12 asparaginase-based asparagine biosensor for leukemia.Artif. Cells Blood Substit. Immobilization Biotechnol., $\quad 35$ : 449-456. http://dx.doi.org/10.1080/1073119070 1460358.

\section{How to cite this article:}

Lalitha Devi, A.S., and Ramanjaneyulu, R. 2016. Isolation of L-Asparaginase Producing Microbial Strains from Soil Samples of Telangana and Andhra Pradesh States, India. Int.J.Curr.Microbiol.App.Sci. 5(10): 1105-1113. doi: http://dx.doi.org/10.20546/ijcmas.2016.510.116 